\title{
CORRECTION
}

\section{Correction to: Quick detection of causative bacteria in cases of acute cholangitis and cholecystitis using a multichannel gene autoanalyzer}

\author{
Ryutaro Watanabe ${ }^{1,2,3} \cdot$ Koji Asai $^{1}$ (1) $\cdot$ Makoto Kuroda ${ }^{2} \cdot$ Manabu Kujiraoka $^{1} \cdot$ Tsuyoshi Sekizuka $^{2} \cdot$ Miwa Katagiri $^{1}$. \\ Nanako Kakizaki ${ }^{1} \cdot$ Hodaka Moriyama $^{1} \cdot$ Manabu Watanabe ${ }^{1} \cdot$ Yoshihisa Saida $^{1}$
}

Published online: 21 February 2022

(c) The Author(s) under exclusive licence to Springer Nature Singapore Pte Ltd. 2022

\section{Correction to: Surgery Today (2021) 51:1938-1945 https://doi.org/10.1007/s00595-021-02332-3}

Publisher's Note Springer Nature remains neutral with regard to jurisdictional claims in published maps and institutional affiliations.

In the original publication, the column headings of Table 5 are incorrectly given as: "Bile culture posiive". The column headings should be: "Bile culture positive". The corrected Table 5 is given in this Correction.

Table 5 Correlation between the maximum colony quantity of the strain isolated in the bile culture and the patient characteristics

\begin{tabular}{|c|c|c|c|c|}
\hline \multirow[t]{2}{*}{ Factors } & \multicolumn{4}{|c|}{ Maximum colony quantity $(\mathrm{CFU} / \mathrm{mL})$} \\
\hline & $\begin{array}{l}\text { Bile culture positive } \geq 10^{6} \\
(n=31)\end{array}$ & $\begin{array}{l}\text { Bile culture positive }<10^{6} \\
(n=25)\end{array}$ & Bile culture negative $(n=52)$ & $p$ \\
\hline $\operatorname{Sex}(M / F)$ & $15 / 16$ & $17 / 8$ & $30 / 22$ & 0.356 \\
\hline Age & $69(31-93)$ & $76(37-89)$ & $67(30-93)$ & 0.091 \\
\hline Body temperature $\left({ }^{\circ} \mathrm{C}\right)$ & $38.2(36.4-39.7)$ & $37.9(37.1-39.6)$ & $37.6(36.7-38.8)$ & $<0.001$ \\
\hline White blood cell $(/ \mu \mathrm{l})$ & $11,500(5600-32,700)$ & $11,700(6200-25,900)$ & $12,500(4900-26,400)$ & 0.644 \\
\hline C-reactive protein $(\mathrm{mg} / \mathrm{dL})$ & $14.34(0.04-28.52)$ & $9.49(0.05-39.48)$ & $7.62(0.07-34.00)$ & 0.352 \\
\hline
\end{tabular}

The original article can be found online at https://doi.org/10.1007/ s00595-021-02332-3.

Koji Asai

k-asai@mvg.biglobe.ne.jp

1 Department of Surgery, Toho University Ohashi Medical Center, 2-22-36 Ohashi, Meguro-ku, Tokyo 153-8515, Japan

2 Laboratory of Bacterial Genomics, Pathogen Genomics Center, National Institute of Infectious Diseases, Tokyo, Japan

3 Department of Clinical Oncology, Toho University Graduate School, Tokyo, Japan 